\title{
Nitrogen Fertilizer Management and Maize Straw Return Modulate Yield and Nitrogen Balance in Sweet Corn
}

\author{
Lei Gao ${ }^{1,+}$, Wu Li ${ }^{1,+}$, Umair Ashraf ${ }^{2}$, Wenjia Lu ${ }^{1}$, Yuliang Li ${ }^{1}$, Chunyan Li ${ }^{1}$, Guangyu Li ${ }^{1}$, \\ Gaoke $\mathrm{Li}^{1}{ }^{1}$ * and Jianguang $\mathrm{Hu}^{1, *}$ \\ 1 Guangdong Provincial Key Laboratory of Crop Genetic Improvement, Crop Research Institute, Guangdong \\ Academy of Agricultural Sciences, Guangzhou 510640, China; gaolei@gdaas.cn (L.G.); liwu@gdaas.cn (W.L.); \\ luwenjia@gdaas.cn (W.L.); liyuliang@gdaas.cn (Y.L.); lichunyan@gdaas.cn (C.L.); \\ liguangyum@163.com (G.L.) \\ 2 Department of Botany, Division of Science and Technology, University of Education, Lahore, Punjab 54770, \\ Pakistan; umairashraf2056@gmail.com \\ * $\quad$ Correspondence: ligaoke@gdaas.cn (G.L.); hujianguang@gdaas.cn (J.H.) \\ + Authors with equal contribution.
}

Received: 24 January 2020; Accepted: 3 March 2020; Published: 5 March 2020

\begin{abstract}
Nitrogen fertilizer is an important component of crop production; however, its excessive application could result in $\mathrm{N}$ loss that could have serious environmental concerns. Straw incorporation in the soil after crop harvest is one of the most feasible straw management techniques, however, the optimization of nitrogen $(\mathrm{N})$ fertilizer management and maize straw incorporation to modulate the crop yield and to maintain $\mathrm{N}$ balance in sweet corn is necessary to get better yields on a sustained basis. The present study was comprised of two straw management treatments i.e., (i) no straw return (S0), and (ii) incorporation of crushed corn ears by into the soil using rotary tiller (S100) and four $\mathrm{N}$ fertilizer management treatments i.e., (i) common farmer practice with total $\mathrm{N}$ applied at $300 \mathrm{~kg} \mathrm{ha}^{-1}$ with 50\%, 5\%, 30\%, and 15\% splits at basal, 3-leaf stage (V3), at hilling stage (V8) and at tasseling/flowering stage (RT), respectively (FM); (ii) application of total $\mathrm{N}$ at $225 \mathrm{~kg} \mathrm{ha}^{-1}$ with $40 \%$, $10 \%$ and 50\% at basal, 3-leaf stage (V3) and at hilling stage (V8), respectively (OMI); (iii) application of total $\mathrm{N}$ at $150 \mathrm{~kg} \mathrm{ha}{ }^{-1}$ with $40 \%, 10 \%$ and 50\% at basal, 3-leaf stage (V3), and at hilling stage (V8), respectively (OMII); and (iv) the treatment without any fertilizer application (N0). The hybrid sweet corn cultivar 'Yuetian 28' was grown during the spring and autumn growing seasons of 2016 and 2017. The results showed that the $\mathrm{N}$ management treatments substantially improved the fresh ear yield, ear number and ear weight, partial factor productivity from nitrogen $\left(\mathrm{PFP}_{\mathrm{N}}\right)$, recovery efficiency from nitrogen $\left(\mathrm{RE}_{\mathrm{N}}\right)$, and agronomic efficiency from nitrogen $\left(\mathrm{AE}_{\mathrm{N}}\right)$. Compared with FM, the OMI and OMII treatments significantly increased the $\mathrm{AE}_{\mathrm{N}}$ and $\mathrm{PFP}_{\mathrm{N}}$ whilst decreased the apparent $\mathrm{N}$ loss, however, the fresh ear yield, ear number and ear weight in OMI treatment were found to be statistically similar $(p>0.05)$ to FM. Moreover, the S100 treatment did not affect the fresh ear yield and yield components significantly. Overall, straw return combined with an optimized $\mathrm{N}$ fertilizer application could improve the yield of sweet corn on a sustained basis with minimum and/or negligible $\mathrm{N}$ loss.
\end{abstract}

Keywords: sweet corn; maize straw; $\mathrm{N}$ use efficiency; $\mathrm{N}$ loss; yield

\section{Introduction}

Nitrogen (N) is a critical nutritional element for crops and is considered as one of the main limiting factors that substantially affects crop yields [1]. The application of $\mathrm{N}$ fertilizers at higher rates 
generally results in higher crop yields [2,3], however, excessive $\mathrm{N}$ application can also cause serious environmental issues $[4,5]$. So, the application of balanced $\mathrm{N}$ dose is necessary to meet the challenge of sustainable crop production with better nitrogen use efficiencies (NUE).

Sweet corn is an important crop that is produced and consumed in South China on a large scale [6]. During its growth period, the local farmers are generally applying high doses of $\mathrm{N}$-fertilizers in curse to get high yields [7,8], however, excessive $\mathrm{N}$ application could result in $\mathrm{N}$ loss into the environment, rather than its better uptake and utilization [9,10], which ultimately leads to serious environmental risks [11]. The crop yield increment is reaching its bottleneck under high $\mathrm{N}$ application and fingerprinting the bad impact on ecological safety $[12,13]$. Therefore, the optimization of $\mathrm{N}$ application is needed in order to get better yields of sweet corn with reduced/minimum $\mathrm{N}$ loss, to make the crop production ecologically safe. Thus, the application of organic fertilizers is an eco-safe approach in crop production systems [14]. The sweet corn straw with high C:N ratio could release plenty of nutrients after returning into the soil [15]. The straw decomposition absorbs available $\mathrm{N}$ in the soil and plays a significant role in reducing $\mathrm{N}$ loss [16] whereas the release of straw-based nutrients after its decomposition is beneficial for crop growth [17]. Being cost-effective, farmers often apply more chemical fertilizers rather than applying organic fertilizers to get short-term benefits [18]. On the other hand, farmers often burn the crop residues for on-farm management without knowing its consequences on soil health [19]. With the development of mechanized farming, it is now quite easy to incorporate the crop residues into the soil rather than to burn, however, the effects of returning straw into the soil with optimized $\mathrm{N}$ dose and their subsequent effects on crop growth and yield need to be investigated. Moreover, it is also important to meet the nutrient requirements of sweet corn during its growth period; therefore, the local farmers are keen to apply fertilizer several times to grow sweet corn at a higher yield [20]. Therefore, it is necessary to evaluate the $\mathrm{N}$ fertilizer management methods to meet the crop nutrient requirements and to reduce the soil $\mathrm{N}$ loss and labor cost for fertilization in the dry land maize planting system. The present study was therefore conducted to evaluate the yield and yield components of sweet corn in response to the $\mathrm{N}$ and straw return treatment into the soil, and to investigate the nitrogen uptake, its utilization, and $\mathrm{N}$ balance for sweet corn with better yields.

\section{Materials and Methods}

\subsection{Experimental Site and Treatments}

Field experiments were conducted during 2016 and 2017 at the Experimental Farm, Guangdong Academy of Agricultural Sciences ( $23^{\circ} 23^{\prime} \mathrm{N}, 113^{\circ} 26^{\prime} \mathrm{E} ; 47 \mathrm{~m}$ elevation), China. The regional climatic conditions are quite suitable for maize production [21]. The meteorological data during the growth period of the crop were obtained from the meteorological station of the Central Meteorological Bureau, Baiyun District, Guangzhou, China and shown in Table 1. The physicochemical soil properties of the top $30 \mathrm{~cm}$ soil layer were determined according to Page et al. [22] The experimental soil was sandy loam, comprising $5.93 \mathrm{~g} \mathrm{~kg}^{-1}$ organic matter, $0.41 \mathrm{~g} \mathrm{~kg}^{-1}$ total $\mathrm{N}$ content, $96.37 \mathrm{mg} \mathrm{kg}^{-1}$ Olsen-P, and $162.86 \mathrm{mg} \mathrm{k} \mathrm{1-3} \mathrm{cm}$ soil depth, with a planting density of 41,619 plants ha $^{-1}$. The sowing and harvest times are shown in Table 2.

The experimental treatments were comprised of two straw management treatments i.e., (i) no straw return (S0), and (ii) incorporation of crushed corn ears by into the soil using rotary tiller (S100). The detailed information about the timing of straw return, sowing and harvest are shown in Table 2. The $\mathrm{N}$ fertilizer management treatments were comprised of: (i) common farmer practice with total $\mathrm{N}$ applied at $300 \mathrm{~kg} \mathrm{ha}^{-1}$ in the form of urea with 50\%, 5\%, 30\%, and 15\% splits at basal, 3-leaf stage (V3), at hilling stage (V8) and at tasseling/ flowering stage (RT), respectively (FM). The $\mathrm{N}$ fertilizer i.e., urea was top-dressed. This farmer practice to apply $\mathrm{N}$ to sweet corn was commonly observed from the main production areas of sweet corn in 'Shuikou', 'Hengli' and 'Ruhu' towns of Huizhou city, Guangdong province, China, (ii) application of total $\mathrm{N}$ at $225 \mathrm{~kg} \mathrm{ha}^{-1}$ in the form of urea with $40 \%, 10 \%$ and $50 \%$ at basal, 3-leaf stage (V3) and at hilling stage (V8), respectively (OMI); (iii) application of total $\mathrm{N}$ at 
$150 \mathrm{~kg} \mathrm{ha}^{-1}$ in the form of urea with $40 \%, 10 \%$ and 50\% at basal, 3-leaf stage (V3), and at hilling stage (V8), respectively (OMII); and (iv) the treatment without any fertilizer application (N0). All treatments were applied with $\mathrm{P}_{2} \mathrm{O}_{5}$ and $\mathrm{K}_{2} \mathrm{O}$ at 120 and $180 \mathrm{~kg} \mathrm{ha}^{-1}$ in the form of calcium dihydrogen phosphate and potassium chloride, respectively, as basal fertilizer before sowing (Table 3). The $\mathrm{N}$ application set up for OMI and OMII was designed according to the results of Huang et al. [23] and Ding et al. [15]

Table 1. Seasonal variations in external environmental conditions during the growth period of sweet corn.

\begin{tabular}{ccccccc}
\hline $\begin{array}{c}\text { Growing } \\
\text { Season }\end{array}$ & $\begin{array}{c}\text { Rainfall } \\
(\mathbf{m m})\end{array}$ & $\begin{array}{c}\text { Sunshine } \\
\text { Hours }(\mathbf{h})\end{array}$ & $\begin{array}{c}\text { Mean } \\
\text { Temperature } \\
\left({ }^{\circ} \mathbf{C}\right)\end{array}$ & $\begin{array}{c}\text { Maximum } \\
\text { Temperature } \\
\left({ }^{\circ} \mathbf{C}\right)\end{array}$ & $\begin{array}{c}\text { Minimum } \\
\text { Temperature } \\
\left({ }^{\circ} \mathbf{C}\right)\end{array}$ & $\begin{array}{c}\text { Daily Total } \\
\text { Solar Radiation } \\
\left(\mathbf{M J} / \mathbf{m}^{\mathbf{2}} \mathbf{)}\right.\end{array}$ \\
\hline 2016spr & 1124.5 & 224.1 & 22.80 & 26.59 & 20.25 & 1005.2 \\
2016aut & 211.0 & 438.9 & 22.20 & 27.16 & 19.07 & 1200.8 \\
2017spr & 828.0 & 273.0 & 22.61 & 26.86 & 19.52 & 1147.1 \\
2017aut & 184.7 & 530.6 & 22.81 & 27.93 & 19.73 & 1284.6 \\
\hline
\end{tabular}

spr: spring, aut: autumn.

Table 2. The information regarding the straw return, crop sowing, and harvest during the experimental period.

\begin{tabular}{ccccccc}
\hline \multirow{2}{*}{$\begin{array}{c}\text { Growing } \\
\text { Season }\end{array}$} & $\begin{array}{c}\text { Intervals (d) } \\
\text { Returning-Sowing }\end{array}$ & Sowing-Harvest & $\begin{array}{c}\text { Harvest-Straw } \\
\text { Returning }\end{array}$ & $\begin{array}{c}\text { Straw } \\
\text { Returning }\end{array}$ & Sowing & Harvest \\
\hline 2016spr & 62 & 99 & 31 & $1 / 4$ & $3 / 6$ & $6 / 12$ \\
2016aut & 61 & 91 & 21 & $7 / 13$ & $9 / 14$ & $12 / 13$ \\
2017spr & 62 & 99 & 26 & $1 / 4$ & $3 / 6$ & $6 / 12$ \\
2017aut & 59 & 92 & - & $7 / 8$ & $9 / 7$ & $12 / 7$ \\
\hline
\end{tabular}

spr: spring, aut: autumn.

Table 3. Description of fertilization management techniques.

\begin{tabular}{cccccc}
\hline & \multicolumn{5}{c}{ Fertilizer Application } \\
\cline { 2 - 6 } & Basal (\%) & Seedling (\%) & Jointing (\%) & Earing (\%) & Total Fertilizer $\mathbf{~ ( k g ~ h m ~}^{\mathbf{- 2}} \mathbf{~}$ \\
\hline FM & 50 & 5 & 30 & 15 & 300 \\
OMI & 40 & 10 & 50 & - & 225 \\
OMII & 40 & 10 & 50 & - & 150 \\
N0 & - & - & - & - & 0 \\
\hline
\end{tabular}

Farmers' $\mathrm{N}$ fertilizer management (FM); application of total $\mathrm{N}$ at $225 \mathrm{~kg} \mathrm{ha}^{-1}$ in the form of urea with $40 \%, 10 \%$ and $50 \%$ at basal, 3-leaf stage (V3) and at hilling stage (V8), respectively (OMI); application of total $\mathrm{N} \mathrm{at} 150 \mathrm{~kg} \mathrm{ha}^{-1}$ in the form of urea with $40 \%, 10 \%$ and $50 \%$ at basal, 3-leaf stage (V3), and at hilling stage (V8), respectively (OMII); Zero-N control (N0).

\subsection{Sampling and Measurements}

Plant samples were harvested at the milk-ripe stage (R3). The three randomly selected plants in each plot were taken, divided into ear and straw and oven-dried to a constant weight at $80^{\circ} \mathrm{C}$. The $\mathrm{N}$ concentrations in dry grain and straw were measured using the Kjeldahl method [24]. At the maturity stage, an area of $21 \mathrm{~m}^{2}$ in the middle of each plot was manually harvested to determine the fresh ear yield (EY) and yield components. The partial factor productivity from nitrogen $\left(\mathrm{PFP}_{\mathrm{N}}\right)$, recovery efficiency from nitrogen $\left(R E_{N}\right)$, and agronomic efficiency from nitrogen $\left(A E_{N}\right)$ were calculated according to the method of Dobermann [25] by using the following formulae:

$$
\mathrm{PFP}_{\mathrm{N}}=\mathrm{Y}_{\mathrm{N}} / \mathrm{F}_{\mathrm{N}}
$$




$$
\begin{gathered}
\operatorname{RE}_{N}=\left(U_{N}-U_{0}\right) / F_{N} \\
\operatorname{PFP}_{N}=Y_{N} / F_{N}
\end{gathered}
$$

$\mathrm{F}_{\mathrm{N}}$-Amount of $\mathrm{N}$ applied $\left(\mathrm{kg} \mathrm{ha}^{-1}\right) ; \mathrm{Y}_{\mathrm{N}}$-crop yield with applied $\mathrm{N}\left(\mathrm{kg} \mathrm{ha}^{-1}\right) ; \mathrm{Y}_{0}$-Crop yield $\left(\mathrm{kg} \mathrm{ha}^{-1}\right)$ in a control treatment without $\mathrm{N} ; \mathrm{U}_{\mathrm{N}}$-Total $\mathrm{N}$ uptake in above-ground biomass at maturity $\left(\mathrm{kg} \mathrm{ha}^{-1}\right)$ in a plot that received $\mathrm{N} ; \mathrm{U}_{0}$-Total $\mathrm{N}$ uptake in above-ground biomass at the milk-ripe stage $\left(\mathrm{kg} \mathrm{ha}^{-1}\right)$ in a plot that received no $\mathrm{N}$.

In addition, the soil samples were collected before sowing and after harvest. Each sample was collected from five sampling locations per plot at 30 and $90 \mathrm{~cm}$ soil depth. The $\mathrm{NH}_{4}+-\mathrm{N}$ and $\mathrm{NO}_{3}-\mathrm{N}$ were analyzed by using the Continuous Flow Analyzer (TRAACS 2000 system, Bran and Luebbe, Norderstedt, Germany). The apparent $\mathrm{N}$ mineralization rate during the sweet corn growing season was calculated as the difference between $\mathrm{N}$ output (plant $\mathrm{N}$ uptake plus residual soil $\mathrm{N}_{\min }$ ) and $\mathrm{N}$ input (initial soil Nmin in the 0-90 cm soil layers) in the N0 treatment [26]. Apparent N losses were calculated as the difference between $\mathrm{N}$ input (initial soil $\mathrm{N}_{\min }$ plus apparent $\mathrm{N}$ mineralization and $\mathrm{N}$ fertilizer) and $\mathrm{N}$ output (plant $\mathrm{N}$ uptake plus residual soil $\mathrm{N}_{\min }$ ) in the $\mathrm{N}$-applied treatments [27].

\subsection{Experimental Design and Data Analysis}

Field experiments were arranged in split-plot design, where straw return treatments were kept in the main plots and the $\mathrm{N}$ fertilizer managements were randomized in the subplots. The plot size was $70 \mathrm{~m}^{2}$ with four replicates. The experimental data were analyzed by using the SPSS21 statistical analysis package (version 6.12, SAS Institute, Cary, NC, USA). The differences amongst means of the experimental treatments were separated by using the least significant difference (LSD) test at 0.05 probability level.

\section{Results}

\subsection{Yield and Yield Components}

The N management treatments significantly affected the fresh ear yield, ear number and ear weight; however, the seasonal effect also affected the ear number substantially. No significant effect of straw return and the interactions of $\mathrm{N} \times$ Straw, $\mathrm{N} \times$ Season, Straw $\times$ Season and $\mathrm{N} \times$ Straw $\times$ Season on fresh ear yield and yield components was detected (Table 4). Compared with N0, the FM, OMI and OMII treatment resulted in a significant increase in fresh ear yield, ear number and ear weight. The fresh ear yield, ear number, and ear weight in OMI treatment remained statistically similar $(p>0.05)$ to FM. The fresh ear yield and ear weight in both growing seasons and the ear number in 2016spr decreased dramatically in OMII compared to FM. Overall, the fresh ear yield was recorded as 5-13.5, 18.6-19.0, 18.7-19.4 and 15.8-16.4 $\mathrm{tha}^{-1}$ for N0, FM, OMI and OMII treatments, respectively (Table 5).

Table 4. Analysis of variance for the fresh ear yield, ear number and ear weight of sweet corn. Levels of significance indicated as: NS = not significant. * Significant at $p \leq 0.05 ;{ }^{* *}$ Significant at $p \leq 0.01$.

\begin{tabular}{cccc}
\hline & Fresh Ear Yield & Ear Number & Ear Weight \\
\hline Tests of Treatment Effect & & & \\
Sum of Square & $5.74 \times 10^{2}$ & 4.65 & $1.48 \times 10^{5}$ \\
Degree of Freedom & 31 & 31 & 31 \\
F-Value & 11.51 & 5.05 & 25.49 \\
ANOVA & & $* *$ & $* *$ \\
N Management & $* *$ & $\mathrm{NS}$ & $\mathrm{NS}$ \\
Straw Management Treatments & $\mathrm{NS}$ & $*$ & $\mathrm{NS}$ \\
Growth Season & $\mathrm{NS}$ & $\mathrm{NS}$ & $\mathrm{NS}$ \\
$\mathrm{N} \times$ Straw & $\mathrm{NS}$ & $\mathrm{NS}$ & $\mathrm{NS}$ \\
$\mathrm{N} \times$ Season & $\mathrm{NS}$ & $\mathrm{NS}$ & $\mathrm{NS}$ \\
Straw $\times$ Season & $\mathrm{NS}$ & $\mathrm{NS}$ & $\mathrm{NS}$ \\
$\mathrm{N} \times$ Straw $\times$ Season & $\mathrm{NS}$ & &
\end{tabular}


Table 5. Yield and yield components of sweet corn under different $\mathrm{N}$ management and straw management treatments.

\begin{tabular}{|c|c|c|c|c|c|c|c|c|c|c|c|c|c|}
\hline \multirow{2}{*}{$\stackrel{\mathrm{N}}{\text { Treatment }}$} & \multirow{2}{*}{$\begin{array}{c}\text { Straw } \\
\text { Return }\end{array}$} & \multicolumn{4}{|c|}{ Fresh Ear Yield (t/ha) } & \multicolumn{4}{|c|}{ Ear Number $\left(10^{4} / \mathrm{ha}\right)$} & \multicolumn{4}{|c|}{ Ear Weight (g) } \\
\hline & & 2016spr & 2016aut & 2017spr & 2017aut & 2016spr & 2016aut & 2017spr & 2017aut & $2016 s p r$ & 2016aut & 2017spr & 2017aut \\
\hline \multirow[t]{3}{*}{ No } & S0 & 13.9 & 10.7 & 8.5 & 5.0 & 4.0 & 3.3 & 2.8 & 2.0 & 343.6 & 327.2 & 307.1 & 247.2 \\
\hline & S100 & 13.0 & 11.5 & 8.9 & 6.5 & 4.1 & 3.6 & 2.9 & 2.4 & 321.2 & 316.9 & 311.9 & 266.2 \\
\hline & Mean & $13.5 \mathrm{C}$ & $11.1 \mathrm{C}$ & $8.7 \mathrm{C}$ & $5.8 \mathrm{C}$ & $4.1 \mathrm{~B}$ & $3.5 \mathrm{C}$ & $2.8 \mathrm{~B}$ & $2.2 \mathrm{~B}$ & $332.4 \mathrm{C}$ & $322.0 \mathrm{C}$ & $309.5 \mathrm{C}$ & $256.7 \mathrm{C}$ \\
\hline \multirow{3}{*}{ FM } & S0 & 19.0 & 18.6 & 18.8 & 18.5 & 4.5 & 4.4 & 4.5 & 4.4 & 424.4 & 424.4 & 421.1 & 424.4 \\
\hline & S100 & 19.0 & 18.2 & 19.2 & 18.7 & 4.4 & 4.3 & 4.5 & 4.3 & 431.8 & 419.1 & 428.1 & 429.9 \\
\hline & Mean & $19.0 \mathrm{~A}$ & $18.4 \mathrm{~A}$ & $19.0 \mathrm{~A}$ & $18.6 \mathrm{~A}$ & $4.4 \mathrm{~A}$ & $4.4 \mathrm{~A}$ & $4.5 \mathrm{~A}$ & $4.4 \mathrm{~A}$ & $428.1 \mathrm{~A}$ & $421.8 \mathrm{~A}$ & $424.6 \mathrm{~A}$ & $427.2 \mathrm{~A}$ \\
\hline \multirow{3}{*}{ OMI } & S0 & 19.0 & 18.8 & 19.1 & 18.4 & 4.4 & 4.5 & 4.5 & 4.4 & 428.1 & 417.4 & 420.9 & 417.0 \\
\hline & $\mathrm{S} 100$ & 18.4 & 19.1 & 19.8 & 19.5 & 4.4 & 4.5 & 4.6 & 4.6 & 422.5 & 420.7 & 426.6 & 424.4 \\
\hline & Mean & $18.7 \mathrm{~A}$ & $19.0 \mathrm{~A}$ & $19.4 \mathrm{~A}$ & $19.0 \mathrm{~A}$ & $4.4 \mathrm{~A}$ & $4.5 \mathrm{~A}$ & $4.6 \mathrm{~A}$ & $4.5 \mathrm{~A}$ & $425.3 \mathrm{~A}$ & $419.0 \mathrm{~A}$ & $423.7 \mathrm{~A}$ & $420.7 \mathrm{~A}$ \\
\hline \multirow{3}{*}{ OMII } & S0 & 16.4 & 15.6 & 16.1 & 15.5 & 4.3 & 4.2 & 4.3 & 4.2 & 376.5 & 373.8 & 376.5 & 371.1 \\
\hline & $\mathrm{S} 100$ & 15.8 & 16.0 & 16.7 & 16.2 & 4.3 & 4.2 & 4.3 & 4.1 & 370.9 & 382.4 & 385.2 & 391.2 \\
\hline & Mean & $16.1 \mathrm{~B}$ & $15.8 \mathrm{~B}$ & $16.4 \mathrm{~B}$ & $15.9 \mathrm{~B}$ & $4.3 \mathrm{~A}$ & $4.2 \mathrm{~B}$ & $4.3 \mathrm{~A}$ & $4.2 \mathrm{~A}$ & 373.7 B & 378.1 B & 380.9 B & $381.1 \mathrm{~B}$ \\
\hline
\end{tabular}

Uppercase letters represent significant differences (LSD $=0.05$ ) among the $\mathrm{N}$ fertilizer rate. FM, Fertilizer management as common farmer practice; OMI, application of total $\mathrm{N}$ at $225 \mathrm{~kg}$ ha ${ }^{-1}$ in the form of urea with $40 \%, 10 \%$ and $50 \%$ at basal, 3-leaf stage (V3) and at hilling stage (V8), respectively; OMII, application of total N at $150 \mathrm{~kg}$ ha ${ }^{-1}$ in the form of urea with $40 \%$, $10 \%$ and $50 \%$ at basal, 3-leaf stage (V3), and at hilling stage (V8), respectively; Control, zero-N control; S0, no straw return to soil; S100, straw return to soil. 


\subsection{Above-Ground N Uptake and N Use Efficiency}

Total nitrogen $\left(\mathrm{T}_{\mathrm{N}}\right)$ is total nitrogen uptake by the plant. $\mathrm{N}$ treatments and growth seasons significantly affected the total nitrogen $\left(T_{N}\right), R E_{N}, A E_{N}$ and $P_{F P}$. Besides, straw return treatment and $\mathrm{N} \times$ Season remarkably affected the $\mathrm{T}_{\mathrm{N}}, \mathrm{RE}_{\mathrm{N}}$ and $\mathrm{AE}_{\mathrm{N}}$. Moreover, the interactive effect of $\mathrm{N} \times \mathrm{Straw}$ on $\mathrm{RE}_{\mathrm{N}}$, Straw $\times$ Season on $\mathrm{AE}_{\mathrm{N}}$ and $\mathrm{PFP}_{\mathrm{N}}$ and $\mathrm{N} \times$ Straw $\times$ Season on $\mathrm{AE}_{\mathrm{N}}$ was also found to be significant (Table 6).

The FM and OMI treatment resulted in significantly higher $\mathrm{T}_{\mathrm{N}}$ than OMII and N0 in 2016spr, 2016aut and 2017spr. The FM, OMI, and OMII treatment showed significantly higher $\mathrm{T}_{\mathrm{N}}$ than N0 in 2017aut. The highest $T_{N}$ in 2016aut $\left(169.1 \mathrm{~kg} \mathrm{ha}^{-1}\right), 2017 \mathrm{spr}\left(196.1 \mathrm{~kg} \mathrm{ha}^{-1}\right)$ and $2017 \mathrm{aut}\left(173.8 \mathrm{~kg} \mathrm{ha}^{-1}\right)$ were recorded for OMI-S100 treatment. Compared with FM, the OMI and OMII treatment showed higher $R E_{N}$, whilst the straw return was found to be beneficial for increased $T_{N}$ and $R E_{N}$ in 2016aut, 2017spr and 2017aut. The OMI treatment significantly increased the $\mathrm{AE}_{\mathrm{N}}$ and $\mathrm{PFP}_{\mathrm{N}}$ compared to FM. The OMII showed substantial improvement in $\mathrm{AE}_{\mathrm{N}}$ (2016aut, 2017spr and 2017aut) and $\mathrm{PFP}_{\mathrm{N}}$ for all growing seasons compared to FM. Straw return improved $\mathrm{AE}_{\mathrm{N}}$ and $\mathrm{PFP}_{\mathrm{N}}$ for OMI and OMII treatment in 2016aut, 2017spr and 2017aut (Table 7).

Table 6. Analysis of variance for $\mathrm{T}_{\mathrm{N}}, \mathrm{RE}_{\mathrm{N}}, \mathrm{AE}_{\mathrm{N}}$, and $\mathrm{PFP}_{\mathrm{N}}$ of sweet corn.

\begin{tabular}{|c|c|c|c|c|}
\hline & $\mathbf{T}_{\mathbf{N}}$ & $\mathrm{RE}_{\mathbf{N}}$ & $\mathrm{AE}_{\mathrm{N}}$ & $\mathbf{P F P}_{\mathbf{N}}$ \\
\hline Tests of Treatment Effect & - & - & - & \\
\hline Sum of Square & $2.04 \times 10^{4}$ & $2.20 \times 10^{4}$ & $2.15 \times 10^{4}$ & $2.39 \times 10^{4}$ \\
\hline Degree of Freedom & 23 & 23 & 23 & 23 \\
\hline F-Value & 28.08 & 376.8 & 421.7 & 112.5 \\
\hline ANOVA & - & - & - & - \\
\hline N Management & $* *$ & $* *$ & $* *$ & $* *$ \\
\hline $\begin{array}{c}\text { Straw Management } \\
\text { Treatments }\end{array}$ & $* *$ & $* *$ & $* *$ & - \\
\hline Grow Season & $* *$ & $* *$ & $* *$ & $*$ \\
\hline $\mathrm{N} \times$ Straw & NS & $*$ & NS & NS \\
\hline $\mathrm{N} \times$ Season & $*$ & $* *$ & $* *$ & NS \\
\hline Straw $\times$ Season & NS & NS & $* *$ & $*$ \\
\hline $\mathrm{N} \times$ Straw $\times$ Season & NS & NS & $*$ & NS \\
\hline
\end{tabular}

Levels of significance indicated as: NS $=$ not significant. ${ }^{*}$ Significant at $p \leq 0.05 ;{ }^{* *}$ Significant at $p \leq 0.01 ; \mathrm{T}_{\mathrm{N}}$, total above-ground $\mathrm{N}$ uptake; $\mathrm{RE}_{\mathrm{N}}$, fertilizer- $\mathrm{N}$ recovery efficiency; $\mathrm{AE}_{\mathrm{N}}$, agronomic $\mathrm{N}$ use efficiency; $\mathrm{PFP}_{\mathrm{N}}$, nitrogen partial factor productivity.

Table 7. Effects of $\mathrm{N}$ fertilizer and straw return on $\mathrm{T}_{\mathrm{N}}$ and $\mathrm{RE}_{\mathrm{N}}$.

\begin{tabular}{|c|c|c|c|c|c|c|c|c|c|}
\hline & \multirow{2}{*}{$\begin{array}{l}\text { Straw } \\
\text { Return }\end{array}$} & \multicolumn{4}{|c|}{$\mathrm{T}_{\mathrm{N}}\left(\mathrm{kg} \mathrm{ha}^{-1}\right)$} & \multicolumn{4}{|c|}{$\mathrm{RE}_{\mathrm{N}}(\%)$} \\
\hline & & 2016spr & 2016aut & 2017spr & 2017aut & 2016 spr & 2016aut & $2017 \mathrm{spr}$ & 2017aut \\
\hline No & S0 & $101.1 \mathrm{c}$ & $83.5 \mathrm{c}$ & $61.4 \mathrm{c}$ & $28.5 \mathrm{~b}$ & - & - & - & - \\
\hline \multirow{2}{*}{ FM } & S100 & $100.8 \mathrm{c}$ & $86.9 \mathrm{c}$ & $78.6 \mathrm{c}$ & $37.1 \mathrm{~b}$ & - & - & - & - \\
\hline & S0 & $160.1 \mathrm{a}$ & $163.4 \mathrm{a}$ & $177.2 \mathrm{a}$ & $169.8 \mathrm{a}$ & $19.6 \mathrm{bc}$ & $26.6 \mathrm{c}$ & $38.6 \mathrm{~b}$ & $47.1 \mathrm{c}$ \\
\hline \multirow{2}{*}{ OMI } & S100 & $157.1 \mathrm{a}$ & 165.8 a & $182.1 \mathrm{a}$ & $173.3 \mathrm{a}$ & 18.7 c & $27.4 \mathrm{c}$ & $40.2 \mathrm{~b}$ & $48.3 \mathrm{c}$ \\
\hline & So & $159.3 \mathrm{a}$ & $161.0 \mathrm{a}$ & $182.1 \mathrm{a}$ & 167.9 a & $25.9 \mathrm{a}$ & $34.4 \mathrm{~b}$ & $53.7 \mathrm{a}$ & $62.0 \mathrm{~b}$ \\
\hline \multirow{3}{*}{ OMII } & S100 & $153.9 \mathrm{a}$ & $169.1 \mathrm{a}$ & $196.1 \mathrm{a}$ & $173.8 \mathrm{a}$ & $23.5 \mathrm{ab}$ & $38.0 \mathrm{a}$ & $59.9 \mathrm{a}$ & $64.6 \mathrm{~b}$ \\
\hline & S0 & $134.8 \mathrm{~b}$ & $135.8 \mathrm{~b}$ & $144.8 \mathrm{~b}$ & $139.2 \mathrm{a}$ & $22.4 \mathrm{~b}$ & $34.8 \mathrm{~b}$ & $55.6 \mathrm{a}$ & $73.8 \mathrm{a}$ \\
\hline & $\mathrm{S} 100$ & $129.8 \mathrm{~b}$ & $140.0 \mathrm{~b}$ & $151.7 \mathrm{~b}$ & $144.0 \mathrm{a}$ & $19.1 \mathrm{c}$ & $37.6 \mathrm{a}$ & $60.2 \mathrm{a}$ & $77.0 \mathrm{a}$ \\
\hline
\end{tabular}

Lowercase letters represent significant differences (LSD = 0.05); FM, fertilizer management as common farmer practice; application of total $\mathrm{N}$ at $225 \mathrm{~kg} \mathrm{ha}^{-1}$ in the form of urea with $40 \%, 10 \%$ and $50 \%$ at basal, 3-leaf stage (V3) and at hilling stage (V8), respectively (OMI); application of total $\mathrm{N}$ at $150 \mathrm{~kg} \mathrm{ha}^{-1}$ in the form of urea with $40 \%, 10 \%$ and $50 \%$ at basal, 3-leaf stage (V3), and at hilling stage (V8), respectively (OMII); control, zero-N control; S0, no straw return to field; $\mathrm{S} 100$, straw return to field. $\mathrm{T}_{\mathrm{N}}$, total above-ground $\mathrm{N}$ uptake; $\mathrm{RE}_{\mathrm{N}}$, fertilizer-N recovery efficiency.

The TN in straw return treatments was comparatively lower than S0 during 2016spr and 2016aut, whereas the results were otherwise during 2017spr and 2017aut. On the other hand, the values of 
TN for N0, FM, OMI, and OMII were found statistically similar $(p>0.05)$ for S0 and S100 for all the growing seasons.

\subsection{Nitrogen Balance}

The OMI and OMII treatment decreased the apparent $\mathrm{N}$ loss when compared with FM treatment, whereas the apparent $\mathrm{N}$ loss under straw return (S100) was lower than without straw return (S0). The apparent $\mathrm{N}$ losses for FM-S0, FM-S100, OMI-S0, OMI-S100, OMII-S0 and OMII-S100 were found to be in the range of 167.3-208.3, 164.4-200.8, 89.8-163.2, 80.6-138.7, 40.6-111.9, and 39.4-90.7 kg N ha ${ }^{-1}$, respectively. The OMII-S100 resulted in the lowest apparent $\mathrm{N}$ loss in 2016spr, 2016aut, 2017spr and 2017aut, i.e., 73.8, 90.7, 72.3 and $39.4 \mathrm{~kg} \mathrm{~N} \mathrm{ha}^{-1}$, respectively (Table 8).

Table 8. Components of the $\mathrm{N}$ balance in the different treatments for the four growing seasons. $\mathrm{N}$ inputs: $\mathrm{N}$ applied with fertilizer ( $\mathrm{N}$ fertilizer), soil mineral $\mathrm{N}$ before sowing $0-0.9 \mathrm{~m}$ ( $\mathrm{N}$ min sowing), apparent $\mathrm{N}$ mineralization ( $\mathrm{N}$ mineralize.); $\mathrm{N}$ outputs: total above-ground $\mathrm{N}$ uptake $\left(\mathrm{T}_{\mathrm{N}}\right)$, soil mineral $\mathrm{N}$ at harvest 0-0.9 $\mathrm{m}$ ( $\mathrm{N}$ min harvest); and apparent $\mathrm{N}$ losses ( $\mathrm{N}$ losses).



Lowercase letters represent significant differences (LSD = 0.05); FM, fertilizer management as common farmer practice; OMI, application of total $\mathrm{N}$ at $225 \mathrm{~kg} \mathrm{ha}^{-1}$ in the form of urea with $40 \%, 10 \%$ and $50 \%$ at basal, 3-leaf stage (V3) and at hilling stage (V8), respectively; OMII, application of total $\mathrm{N}$ at $150 \mathrm{~kg} \mathrm{~h}^{-1}$ in the form of urea with $40 \%$, $10 \%$ and $50 \%$ at basal, 3-leaf stage (V3), and at hilling stage (V8), respectively; control, zero-N control; S0, no straw return to the field; 5100 , straw return to field.

\section{Discussion}

In general, farmers focused on obtaining high benefits by obtaining higher crop yields, and ignored the various other factors that are directly and/or indirectly related to sustainable crop production and farmers' income. For example, the application of excess $\mathrm{N}$ in order to get higher yields often 
leads to low $\mathrm{N}$ use efficiencies, whereas straw burning (just for on-farm straw management) causes environmental pollution and could also have severe consequences for soil physicochemical and biological properties [18,28-30]. Moreover, during the 2016 and 2017 growing seasons, the straw returned to the field combined with the appropriate $\mathrm{N}$ fertilizer management improved maize yield, i.e., $\mathrm{FM}>\mathrm{OMI}>\mathrm{OMII}>\mathrm{N} 0$, whereas the mean values for fresh ear yield were found to be statistically similar $(p>0.05)$ for FM and OMI (Table 5). Previously, Xu et al. [31] reported that the straw returning + fertilizer application treatment increased the yield of the rice. The short-term effect of crop straw return on yield was not that obvious due to the fact that $\mathrm{N}$ fertilizer had a stronger effect than straw return [32-35].

The better $\mathrm{N}$ balance may possibly be the result of higher $\mathrm{N}$ uptake in OMI and OMII. Moreover, it is a practical approach to establish the nitrogen management practices by evaluating the yield, nitrogen absorption and use efficiencies [36]. Integrated fertilizer management has a significant impact on crop production and $\mathrm{N}$ balance in the crop-soil system [14]. In this study, the nitrogen absorption in FM and OMI treatment, under no straw return (S0), was $160.1-177.2 \mathrm{~kg} \mathrm{ha}^{-1}$ and 159.3-182.1 kg ha-1, respectively (Table 7), which is in accordance with the findings of Gao et al. [20]. The $\mathrm{T}_{\mathrm{N}}$ in straw return treatment was comparatively lower than S0 during 2016spr and 2016aut but not during 2017spr and 2017 aut. On the other hand, the values of $\mathrm{T}_{\mathrm{N}}$ for N0, FM, OMI, and OMII were found to be statistically similar $(p>0.05)$ for $\mathrm{S} 0$ and $\mathrm{S} 100$, for all the growing seasons. The $\mathrm{T}_{\mathrm{N}}$ in straw return treatments was comparatively lower than S0 during 2016spr and 2016aut, whereas the results were otherwise during 2017spr and 2017aut. On the other hand, the values of $\mathrm{T}_{\mathrm{N}}$ for N0, FM, OMI, and OMII were found to be statistically similar $(p>0.05)$ for $\mathrm{S} 0$ and S100, for all the growing seasons (Table 7). The previous study reported that $\mathrm{N}$ loss has increased due to excessive N-based fertilizers [37]. Compared with S0, straw return (S100) was found to be beneficial in N uptake and use efficiencies in maize. Previously, Liu et al. [37] reported that integrated agronomic practices management improved in yield, nitrogen balance, but reduced nitrogen loss. The $\mathrm{N}$ loss due to $\mathrm{N}$ leaching is the largest source under the high $\mathrm{N}$ application in South China, as a consequence of high-temperature and heavy-rain climate conditions [38]. Thus, FM treatment produced the highest nitrogen loss, due to nitrogen leaching, and besides, the straw return treatment showed lower $\mathrm{N}$ loss than no straw return treatment. Further, $\mathrm{OMI}+\mathrm{S} 100$ treatment showed better $\mathrm{N}$ uptake (Table 8), which showed that the addition of straw in combination with $\mathrm{N}$ application could substantially improve the $\mathrm{N}$ uptake in maize. Alterations in crop production practices due to diversity in cropping systems (specifically the inclusion of leguminous crops) could substantially improve the nutrient use efficiencies [39]. Moreover, the application of organic fertilizers and green manuring also improved the $\mathrm{N}$ uptake, use efficiency and crop yield [40]. Moreover, the deep placement of $\mathrm{N}$ fertilizer and organic amendments in addition to chemical fertilizers could also improve the overall $\mathrm{N}$ use efficiency, thus could also be a potential $\mathrm{N}$ management strategy in cereal crops [41-43].

Without a doubt, the common practice followed by farmers could also produce high yield, but often leads to the leaching of $\mathrm{N}$. The optimization of $\mathrm{N}$ fertilizer management and maize straw return is thus necessary to get better crop yields with improved N use efficiency. The OMI + S100 treatment may contribute to both high yields with better $\mathrm{N}$ use efficiency in long term practice. Therefore, the long term management of $\mathrm{N}$ fertilizer is necessary to reduce the $\mathrm{N}$ application rate with minimum loss in the double maize cropping system in South China. Further studies are still needed to better understand the saturation value of soil $\mathrm{N}$ pool, the different routes for $\mathrm{N}$ loss, and soil $\mathrm{N}$ dynamics.

\section{Conclusions}

In summary, the modified application of $\mathrm{N}$ coupled with incorporation maize improved the fresh ear yield, ear number and ear weight, partial factor productivity from nitrogen $\left(\mathrm{PFP}_{\mathrm{N}}\right)$, recovery efficiency from nitrogen $\left(\mathrm{RE}_{\mathrm{N}}\right)$, and agronomic efficiency from nitrogen $\left(A E_{N}\right)$, as compared to farmers' common practice of the $\mathrm{N}$ application in sweet corn. The OMI and OMII substantially enhanced the $\mathrm{AE}_{\mathrm{N}}$ and $\mathrm{PFP}_{\mathrm{N}}$, however, the yield and related attributes in OMI treatment were found to be marginally 
different than in FM. Therefore, straw incorporation could improve the nitrogen use efficiencies and hence the yield of sweet corn in the long run. Hence, it is feasible to modulate the yield and $\mathrm{N}$ balance of sweet corn by optimizing $\mathrm{N}$ fertilizer management and maize straw return.

Author Contributions: Author Contributions: L.G. (Lei Gao ), W.L. (Wu Li), G.L. (Gaoke Li), C.L. and J.H. designed the research; L.G. (Lei Gao ), W.L. (Wu Li), W.L. (Wenjia Lu), Y.L. performed the experiments and collected the data; L.G. (Lei Gao ), W.L. (Wu Li), and U.A. analyzed the data and wrote the manuscript; L.G. (Lei Gao ), W.L. (Wu Li), U.A., W.L. (Wenjia Lu), Y.L., G.L. (Gaoke Li), J.H. and G.L. (Guangyu Li) edited the manuscript and provided guidance during experimentation. All authors have read and agreed to the published version of the manuscript.

Funding: The National Key R\&D Program Project: 2018YFD0200700. The Project of the Guangdong Province Science and Technology Program: 2018B020202008, 2017B020203003. Guangdong Agricultural Seed Industry Common Key Technical Innovation Team: 2019KJ106. Guangzhou Rural Science and Technology Commissioner Project: GZKTP201815. Team Building Project of Guangdong Academy of Agricultural Sciences: 201610TD

Acknowledgments: This research was funded by the National Key R\&D Program Project, 2018YFD0200700 and the Project of the Guangdong Province Science and Technology Program, 2018B020202008 and 2017B020203003 and Guangdong Agricultural Seed Industry Common Key Technical Innovation Team, 2019KJ106 and Guangzhou Rural Science and Technology Commissioner Project, GZKTP201815 and Guangdong Province Corn Industry Innovation Team Project, Yue Nong Nong Han 20191019 and Discipline team building projects of Guangdong Academy of Agricultural Sciences in the 13th Five-Year Period, 201610TD. The APC was funded by the Project of the Guangdong Province Science and Technology Program, 2017B020203003

Conflicts of Interest: The authors declare no conflict of interest.

\section{References}

1. Ferguson, R.B.; Hergert, G.W.; Schepers, J.S.; Gotway, C.A.; Cahoon, J.E.; Peterson, T.A. Site-specific nitrogen management of irrigated maize. Soil Sci. Soc. Am. J. 2002, 66, 544-553.

2. Tilman, D.; Balzer, C.; Hill, J.; Befort, B.L. Global food demand and the sustainable intensification of agriculture. Proc. Natl. Acad. Sci. USA 2011, 108, 20260-20264. [CrossRef] [PubMed]

3. Fan, M.; Shen, J.; Yuan, L.; Jiang, R.; Zhang, F. Improving crop productivity and resource use efficiency to ensure food security and environmental quality in China. J. Exp. Bot. 2011, 63, 13-24. [CrossRef] [PubMed]

4. Cui, Z.; Zhang, F.; Chen, X.; Dou, Z.; Li, Z. In-season nitrogen management strategy for winter wheat: Maximizing yields, minimizing environmental impact in an over-fertilization context. Field Crops Res. 2010, 116, 140-146. [CrossRef]

5. Hirel, B.; Tétu, T.; Lea, P.J.; Dubois, F. Improving nitrogen use efficiency in crops for sustainable agriculture. Sustainalility 2011, 3, 1452-1485. [CrossRef]

6. Liu, W.; Wan, Z.; Gan, Y.; Hu, J.; Yin, Y. Development situation andcountermeasures of Guangdong sweet corn industry in 2015. Guangdong Agric. Sci. 2016, 43, 12-16, (In Chinese with English Abstract).

7. Zhang, B.; Chen, Q.; Luo, S.; Li, Q.; Cao, J.; Zhang, M.; Zhong, Y.; Yang, Q. Research on index system forsweet maize fertilization in Guangdong. Guangdong Agric. Sci. 2013, 40, 67-70, (In Chinese with English Abstract).

8. Wang, J.; Shao, L.; Yan, J.; Wang, R.; Pang, X.; Zhang, X. Influence of fertilization anddensity on sweet maize ear commodity and soil characters. Guizhou Agric. Sci. 2016, 44, 38-42, (In Chinese with English Abstract).

9. Yan, L.; Zhang, Z.; Zhang, J.; Gao, Q.; Feng, G.; Abelrahman, A.M.; Chen, Y. Effects of improving nitrogen management on nitrogen utilization, nitrogen balance, and reactive nitrogen losses in a Mollisol with maize monoculture in Northeast China. Environ. Sci. Pollut. Res. 2016, 23, 4576-4584. [CrossRef]

10. Omonode, R.A.; Halvorson, A.D.; Gagnon, B.; Vyn, T.J. Achieving lower nitrogen balance and higher nitrogen recovery efficiency reduces nitrous oxide emissions in North America's maize cropping systems. Front. Plant Sci. 2017, 8, 1080. [CrossRef]

11. Liu, X.; Ju, X.; Zhang, F.; Pan, J.; Christie, P. Nitrogen dynamics and budgets in a winter wheat-maize cropping system in the North China Plain. Field Crops Res. 2003, 83, 111-124. [CrossRef]

12. Jin, L.; Cui, H.; Li, B.; Zhang, J.; Dong, S.; Liu, P. Effects of integrated agronomic management practices on yield and nitrogen efficiency of summer maize in North China. Field Crops Res. 2002, 134, 30-35. [CrossRef]

13. Chen, X.; Cui, Z.; Fan, M.; Vitousek, P.; Zhao, M.; Ma, W.; Wang, Z.; Zhang, W.; Yan, X.; Yang, J.; et al. Producing more grain with lower environmental costs. Nature 2014, 514, 486-489. [CrossRef] [PubMed] 
14. Tilman, D.; Cassman, K.G.; Matson, P.A.; Naylor, R.; Polasky, S. Agricultural sustainability and intensive production practices. Nature 2002, 418, 671-677. [CrossRef] [PubMed]

15. Ding, W.C.; Li, S.T.; Huang, S.M. Bioavailability and fate of nitrogen from ${ }^{15} \mathrm{~N}$-labeled corn straw as affected by nitrogen management and straw microbial inoculants. Sci. Agric. Sin. 2016, 49, 2725-2736, (In Chinese with English Abstract).

16. Zhu, C.; Li, Z.; Wu, W.; Yang, P. Carbon and nitrogen mineralization of incubated sweet maize and white clover straw. Chin. J. Eco-Agric. 2009, 17, 423-428, (In Chinese with English Abstract). [CrossRef]

17. Peng, W.; Chu, C.; Zhong, Y.; Lai, W.; Zhang, H.; Huang, L.; Shi, X.; Wei, J. Effects of returning to field of sweet corn straw on soil fertility, yield and benefit. Guangdong Agric. Sci. 2015, 42, 25-30, (In Chinese with English Abstract).

18. Miao, Y.; Stewart, B.; Zhang, F. Long-term experiments for sustainable nutrient management in China. A review. Agron. Sustain. Dev. 2011, 31, 397-414. [CrossRef]

19. Xie, Z.; Li, Y.; Yu, Z. Impacts of residue return on nitrogen utilization in crops: A review. Soils Crops 2016, 5, 261-268, (In Chinese with English Abstract).

20. Gao, L.; Li, Y.; Li, W.; Yu, T.; Li, G.; Li, C.; Hu, J. Effects of nitrogen application on yields and nitrogen use efficiencies of sweet corn in south China. J. Plant Nutr. Fertil. 2017, 23, 1215-1224, (In Chinese with English Abstract).

21. Gao, L.; Hu, J.; Wen, T.; Li, C.; Li, W. Effects of growing season on yield and yield components of sweet corn. Guangdong Agric. Sci. 2016, 1, 11-14, (In Chinese with English Abstract).

22. Page, A.L.; Miller, R.H.; Keeney, D.R. Methods of soil analysis. Part 2. American Society of Agronomy. Soil Sci. Soc. Am. J. 1982, 9, 413-414.

23. Huang, T.; Zheng, X.; Hou, Y.; Li, X.; Wang, Z. Yield and N, P and K uptake and utilization of winter wheat affected by straw return to soil. J. Plant Nutr. Fertil. 2015, 21, 853-863, (In Chinese with English Abstract).

24. Horowitz, W. Official Methods of Analysis of the Association of Official Analytical Chemists, 11th ed.; AOAC: Washington, DC, USA, 1970.

25. Dobermann, A. Nitrogen Use Efficiency-State of the Art; IFA International Workshop on Enhanced-Efficiency Fertilizers: Frankfurt, Germany, 2005.

26. Meisinger, J. Evaluating plant-available nitrogen in soil-crop systems. Nitrogen Crop Prod. 1984, $389-416$. [CrossRef]

27. Ma, B.; Dwyer, L.; Gregorich, E. Soil nitrogen amendment effects on seasonal nitrogen mineralization and nitrogen cycling in maize production. Agron. J. 1999, 91, 1003-1009. [CrossRef]

28. Chen, X.; Cui, Z.; Vitousek, P.; Cassman, K.G.; Matson, P.A.; Bai, J.; Meng, Q.; Hou, P.; Yue, S.; Römheld, V.; et al. Integrated soil-crop system management for food security. Proc. Natl. Acad. Sci. USA 2011, 108, 6399-6404. [CrossRef]

29. Cui, Y.; Jun, M.; Wang, Q.; Zhang, W.; Cheng, X.; Chen, W. Effects of straw and biochar addition on soil nitrogen, carbon, and super rice yield in cold waterlogged paddy soils of North China. J. Integr. Agric. 2017, 16, 1064-1074. [CrossRef]

30. Zhang, H.; Yu, C.; Kong, X.; Huo, D.; Gu, J.; Liu, L.; Wang, Z.; Yang, J. Progressive integrative crop managements increase grain yield, nitrogen use efficiency and irrigation water productivity in rice. Field Crops Res. 2018, 215, 1-11. [CrossRef]

31. Xu, Y.; Nie, L.; Buresh, R.; Huang, J.; Cui, K.; Xu, B.; Gong, W.; Peng, S. Agronomic performance of late-season rice under different tillage, straw, and nitrogen management. Field Crops Res. 2010, 115, 79-84. [CrossRef]

32. Eagle, A.J.; Bird, J.A.; Horwath, W.R.; Linquist, B.A.; Brouder, S.M.; Hill, J.E.; Kessel, C.V. Rice yield and nitrogen utilization efficiency under alternative straw management practices. Agron. J. 2000, 92, 1096-1103. [CrossRef]

33. Phongpan, S.; Mosier, A.R. Effect of crop residue management on nitrogen dynamics and balance in a lowland rice cropping system. Nutr. Cycl. Agroecosys. 2003, 66, 133-142. [CrossRef]

34. Phongpan, S.; Mosier, A.R. Effect of rice straw management on nitrogen balance and residual effect of urea-N in an annual lowland rice cropping sequence. Biol. Fertil. Soils 2003, 37, 102-107. [CrossRef]

35. Phongpan, S.; Mosier, A.R. Impact of organic residue management on nitrogen use efficiency in an annual rice cropping sequence of lowland Central Thailand. Nutr. Cycl. Agroecosys. 2003, 66, 233-240. [CrossRef]

36. Setiyono, T.D.; Walters, D.T.; Cassman, K.G.; Witt, C.; Dobermann, A. Estimating maize nutrient uptake requirements. Field Crops Res. 2010, 118, 158-168. [CrossRef] 
37. Liu, Z.; Gao, J.; Gao, F.; Dong, S.; Liu, P.; Zhao, B.; Zhang, J. Integrated agronomic practices management improve yield and nitrogen balance in double cropping of winter wheat-summer maize. Field Crops Res. 2018, 221, 196-206. [CrossRef]

38. Ju, X. The concept and meanings of nitrogen fertilizer availability ratio-discussing misunderstanding of traditional nitrogen use efficiency. Acta Pedol. Sin. 2014, 51, 921-933, (In Chinese with English Abstract).

39. Deligios, P.A.; Tiloca, M.T.; Sulas, L.; Buffa, M.; Caraffini, S.; Doro, L.; Sanna, G.; Spanu, E.; Spissu, E.; Urracci, G.R.; et al. Stable nutrient flows in sustainable and alternative cropping systems of globe artichoke. Agron. Sustain. Dev. 2017, 37, 54. [CrossRef]

40. Montemurro, F.; Fiore, A.; Campanelli, G.; Tittarelli, F.; Ledda, L.; Canali, S. Organic fertilization, green manure, and vetch mulch to improve organic zucchini yield and quality. HortScience 2013, 48, 1027-1033. [CrossRef]

41. Pan, S.; Wen, X.; Wang, Z.; Ashraf, U.; Tian, H.; Duan, M.; Mo, Z.; Fan, P.; Tang, X. Benefits of mechanized deep placement of nitrogen fertilizer in direct-seeded rice in South China. Field Crops Res. 2017, 203, 139-149. [CrossRef]

42. Wang, L.; Ashraf, U.; Chang, C.; Abrar, M.; Cheng, X. Effects of Silicon and Phosphatic Fertilization on Rice Yield and Soil Fertility. J. Soil Sci. Plant Nutr. 2019, 16, 1-9. [CrossRef]

43. Mahmood, F.; Khan, I.; Ashraf, U.; Shahzad, T.; Hussain, S.; Shahid, M.; Abid, M.; Ullah, S. Effects of organic and inorganic manures on maize and their residual impact on soil physico-chemical properties. J. Soil Sci. Plant Nutr. 2017, 17, 22-32. [CrossRef]

(C) 2020 by the authors. Licensee MDPI, Basel, Switzerland. This article is an open access article distributed under the terms and conditions of the Creative Commons Attribution (CC BY) license (http://creativecommons.org/licenses/by/4.0/). 